\title{
Glosa aprobująca do uchwały Sądu Najwyższego z dnia 24 stycznia 2020 roku (sygn. III CZP 51/19)
}

Celem niniejszej glosy jest omówienie uchwały Sqdu Najwyższego z dnia 24 stycznia 2020 roku, wydanej w sprawie o sygn. akt III CZP 51/19. Uchwała została wydana w odpowiedzi na zagadnienie prawne skierowane przez sqd okręgowy w Szczecinie w zwiqzku z rozbieżnościami w orzecznictwie sqdów powszechnych. Orzeczenie dotyczy charakteru prawnego kwoty wypłacanej przez ubezpieczyciela w przypadku przedterminowego rozwiqzania umowy ubezpieczenia na życie z ubezpieczeniowym funduszem kapitałowym. Wocenie autorki Sad Najwyższy prawidłowo wskazał, że wypłata kwoty pieniężnej przez ubezpieczyciela w przypadku przedterminowego rozwiqzania umowy ubezpieczenia na życie z ubezpieczeniowym funduszem kapitałowym nie jest świadczeniem głównym w rozumieniu art. $385^{1} \S 1$ zd. 2 k.c. Autorka twierdzi, że wydanie kwoty wykupu nie stanowi świadczenia w rozumieniu art. 353 k.c. Postanowienia umowy określajace „świadczenie wykupu, wartość wykupu, kwotę wykupu" podlegajq zatem kontroli z punktu widzenia ich abuzywności.

Słowa kluczowe: ubezpieczeniowy fundusz kapitałowy, świadczenie wykupu, wartość wykupu, umowa ubezpieczenia, rozwiązanie umowy.

\section{Glosa}

Na wstępie należy wskazać doniosłe znaczenie - zarówno teoretyczne, jak i praktyczne - wydanej przez Są Najwyższy uchwały w sprawie o sygn. akt III CZP 51/19. Już w 2016 roku Rzecznik Finansowy w części ll raportu Ubezpieczenia na życie z ubezpieczeniowym funduszem kapitałowym stwierdził, że wielokrotnie i coraz częściej podnoszonym przez ubezpieczycieli argumentem przeciwko zasadności powództw konsumentów, opartych o abuzywność postanowień umownych, na podstawie których są dokonywane potrącenia z przypadających im świadczeń wykupu, jest zarzut, że zarówno opłaty likwidacyjne, jak i świadczenia wykupu stanowia główne świadczenia 
w umowie ubezpieczenia na życie z ubezpieczeniowym funduszem kapitałowym ${ }^{1}$. Przyjęcie takiego stanowiska powoduje bowiem, że dalsze badanie postanowień umowy, czy też ogólnych warunków ubezpieczenia (dalej: OWU), staje się bezprzedmiotowe, jako że zgodnie z art. $385^{1} \S 1$ k.c. uzgodnione indywidualnie, główne świadczenia stron, które zostały sformułowane w sposób jednoznaczny, nie podlegaja kontroli pod kątem abuzywności. Wydana uchwała położyła kres niepewności prawnej, jaka miała miejsce na skutek rozbieżności w orzecznictwie.

W stanie faktycznym sprawy ubezpieczająca w latach 2007-2012 zawarła pięć umów ubezpieczenia z ubezpieczeniowym funduszem kapitałowym. Strony wiązały również OWU, określające zasady wypowiadania umów, w tym konieczność poniesienia opłaty likwidacyjnej, opłaty od wykupu, jak również wskazywały sposób obliczenia wysokości tych należności. Opłata od wykupu została określona procentowo w stosunku, w jakim w dniu jej naliczenia pozostawała do wypłaty wartości podstawowej polisy. Zgodnie z tabelą opłat i limitów wskaźnik wykupu w pierwszym i drugim roku nie był w ogóle przewidziany, w roku trzecim stanowił $20 \%$, w czwartym roku - 40\%, w piątym roku - 60\%, w szóstym - 70\%, siódmym - 75\%, ósmym - 80\%, dziewiątym - 84\%, dziesiątym - $88 \%$ od jedenastego do dziewiętnastego roku - 99,5\%, a od dwudziestego roku - $100 \%$. Natomiast opłata likwidacyjna była, zgodnie z OWU, pobierana od kwot należnych ubezpieczającemu z tytułu wypłaty wartości polisy. Opłata ta stanowiła iloczyn wskaźnika określonego w tabeli opłat i limitów oraz łącznej wartości składki podstawowej należnej za pierwszy rok polisy². W 2016 roku ubezpieczająca wypowiedziała wszystkie umowy, domagając się wypłaty środków znajdujących się na jej kontach. W tym dniu łączna wartość umów wynosiła 93 774,98 zł, natomiast ubezpieczyciel wypłacił powódce kwotę 75 887,54 zł. Ubezpieczająca w pozwie domagała się zasądzenia pozostałej kwoty, to jest 17887,44 zł. Zdaniem ubezpieczyciela kwota ta stanowiła wynikająca z OWU sumę opłaty likwidacyjnej, opłaty od wykupu oraz wskaźnika wykupu i jako taka nie była należna powódce. Rozpoznający sprawę w I instancji sąd rejonowy uznał postanowienia OWU dotyczące spornych należności za niedozwolone w rozumieniu art. $385^{1}$ k.c. Uzasadniając orzeczenie, sąd wskazał, że postanowienia te kształtuja prawa konsumenta w sposób sprzeczny z dobrymi obyczajami, rażąco naruszaja jego interesy, nie dotyczą głównych świadczeń stron, jak również nie zostały uzgodnione indywidualnie z powódką. Rozpoznając wniesioną przez ubezpieczyciela apelację, sąd okręgowy powziął wątpliwości co do charakteru prawnego „świadczenia wykupu”. Efektem tych wątpliwości było skierowanie do Sąu Najwyższego zagadnienia prawnego o treści: „Czy świadczenie wykupu, wypłacone przez ubezpieczyciela konsumentowi na podstawie umowy ubezpieczenia na życie z ubezpieczeniowym funduszem kapitałowym w związku z przedterminowym rozwiązaniem tej umowy, jest świadczeniem głównym w rozumieniu art. $385^{1}$ k.c.?". Sąd Najwyższy w glosowanej uchwale stwierdził, że świadczenie wypłacane przez ubezpieczyciela w przypadku przedterminowego rozwiązania umowy ubezpieczenia na życie z ubezpieczeniowym funduszem kapitałowym nie jest świadczeniem głównym w rozumieniu art. $385^{1} \S 1$ zd. 2 k.c.

1. Raport Rzecznika Finansowego, Ubezpieczenia na życie z ubezpieczeniowym funduszem kapitałowym. Część II, Warszawa 2016, s. 38.

2. Postanowienie sądu okręgowego w Szczecinie z dnia 22 maja 2019 r., w przedmiocie przedstawienia Sądowi Najwyższemu pytania prawnego, sygn. II Ca 1300/18, s. 2-3. 
W pierwszej kolejności podkreślenia wymaga, iż Sąd Najwyższy rozpoznawał kilka lat wcześniej sprawę na podstawie pytania prawnego o analogicznej treści ${ }^{3}$. W sprawie tej Rzecznik Finansowy skierował do Sądu Najwyższego oświadczenie przedstawiające istotny pogląd w sprawie, w którym stwierdził, że wartość wykupu nie stanowi głównego świadczenia z umowy ubezpieczenia na życie z ubezpieczeniowym funduszem kapitałowym, a w szczególności nie jest świadczeniem w rozumieniu art. 353 k.c. Mimo że już wtedy istniały rozbieżności w orzecznictwie Sąd Najwyższy postanowieniem z dnia 3 grudnia 2015 roku, wydanym w sprawie o sygn. III CZP 87/15, odmówił podjęcia uchwały. Argumentując zasadność tego postanowienia, skład sędziowski wskazał, że w uzasadnieniu przedstawionego zagadnienia prawnego nie przytoczono wprost postanowienia umownego, które miałoby podlegać kontroli sądowej. Ponadto Sąd Najwyższy wskazał, że „przedstawione zagadnienie prawne odnosi się do określonego typu klauzuli, a nie do klauzuli zindywidualizowanej, nawiązującej do umowy łączącej powoda z ubezpieczycielem. Tymczasem w obrocie prawnym występuje obecnie wiele wariantów umowy ubezpieczenia z ubezpieczeniowym funduszem kapitałowym, a ustawodawca dokonał jedynie szczątkowej regulacji tej umowy, pozostawiajac spory margines swobody dla określenia we wzorcach umownych treści wariantów tej umowy. [...] Czym innym jest zatem kwestia, czy dany typ klauzuli umownej może być zaliczony do postanowień określających główne świadczenie stron w rozumieniu art. $385^{1} \S 1$ zdanie drugie k.c., a czym innym, czy określona, zindywidualizowana klauzula umowna, wskazana w określonym wzorcu umownym, przy uwzględnieniu całego kontekstu wiążącego strony stosunku prawnego, może być także poddana takiej samej kwalifikacji prawnej". Rozpoznając sprawę będącą przedmiotem glosowanej uchwały, Sąd Najwyższy, odmiennie niż w postanowieniu wydanym w sprawie o sygn. III CZP 87/15, uznał, że można dokonać oceny typu klauzuli umownej określającej wypłatę kwoty wykupu pod kątem tego, czy klauzula kształtuje główne świadczenie stron mimo że w dalszym ciagu regulacja prawna dotycząca umowy ubezpieczenia z UFK jest szczątkowa, jak również nadal istnieje wiele wariantów ukształtowania stosunków łączących strony umowy we wzorach umownych. Komentowane orzeczenie stanowi wyraz odejścia przez Są Najwyższy od wcześniej prezentowanego stanowiska w kwestii możliwości oceny charakteru prawnego typu klauzuli umownej określającej obowiązek ubezpieczyciela polegający na wydaniu kwoty wykupu. Michał Romanowski wskazuje, że świadczenie wykupu jest to suma pieniężna, jakiej może żądać ubezpieczający od ubezpieczyciela w razie zakończenia umowy przez ubezpieczającego. Jest to prawo ubezpieczającego do tzw. wykupu polisy ubezpieczenia ${ }^{4}$. Odmiennie Wojciech Kamieński wskazuje, że wydanie kwoty wykupu, nie jest świadczeniem w rozumieniu art. 353 k.c. ${ }^{5}$ Autor twierdzi, że od świadczeń występujących w umowie ubezpieczenia na życie z ubezpieczeniowym funduszem kapitałowym należy odróżnić inne zachowania stron, w tym takie, które mają charakter konkretnych obowiazzków innych niż dług i wierzytelność. Do obowiązków ubezpieczyciela innych niż dług należy wydanie kwoty wykupu (tzw. wykup

3. Sąd okręgowy w Warszawie w sprawie o sygn. V Ca 568/15 postanowieniem z dnia 24 lipca 2015 r. przedstawił Sądowi Najwyższemu pytanie prawne o treści: „Czy świadczenie wypłacane przez ubezpieczyciela w przypadku przedterminowego rozwiązania umowy ubezpieczenia na życie wraz z ubezpieczeniowym funduszem kapitałowym jest świadczeniem głównym, czy ubocznym?".

4. M. Romanowski, Czy świadczenie wykupu w umowach z UFK jest świadczeniem głównym?, „Wiadomości Ubezpieczeniowe" 2016, nr 2, s. 59.

5. W. Kamieński, Główne świadczenia stron umowy ubezpieczenia na życie z ubezpieczeniowym funduszem kapitałowym, „Rozprawy Ubezpieczeniowe” 2014, nr 17, s. 56. 
ubezpieczenia] ${ }^{6}$. W nauce prawa ubezpieczeniowego wyróżnia się elementy zobowiązania, które nie mają charakteru świadczenia. Bartosz Kucharski wskazuje, że „istnieja pewne uboczne obowiązki ubezpieczyciela, polegające na powinności doręczenia dokumentu ubezpieczenia, ogólnych warunków ubezpieczenia, protokołu rozbieżności między umową oraz OWU, na pisemnym zwróceniu uwagi na niekorzystne w stosunku do złożonego wniosku postanowienia dokumentu ubezpieczenia i na wyznaczeniu terminu do złożenia sprzeciwu, nie wydają się bowiem składać na treść jego świadczenia"? Taki charakter ma również wypłata kwoty wykupu. Świadczeniem ubezpieczyciela jest zarządzanie środkami pieniężnymi przekazanymi przez ubezpieczającego i za to otrzymuje on wynagrodzenie. Ubezpieczający ma prawo wypowiedzenia umowy ubezpieczenia z UKF, a tym samym zakończenia stosunku prawnego łączącego go z ubezpieczycielem. W takim wypadku ubezpieczyciel zobowiązany jest do wydania kwoty odpowiadającej wartości jednostek uczestnictwa zapisanych na jego rachunku, pomniejszonych o opłatę likwidacyjna (wydatki poniesione przez ubezpieczyciela). Wydanie kwoty wykupu jest zatem obowiązkiem ubezpieczyciela, rodzajem „powinności” o charakterze technicznym. Wypłata kwoty wykupu nie powoduje przysporzenia majątkowego po stronie ubezpieczonego, a jedynie zmianę postaci składnika majątkowego z jednostki uczestnictwa w funduszu inwestycyjnym zapisanej na indywidualnym rachunku - na środki pieniężne. „Wypłata kwoty wykupu jest obowiązkiem obciążającym ubezpieczyciela, obowiązkiem odrębnym od długu. Wypłata kwoty wykupu we właściwej wysokości oraz we właściwym terminie jest wyznacznikiem należytego wykonania zobowiązania, polegającego na zwrotnym przeniesieniu na ubezpieczającego środków pieniężnych stanowiących równowartość aktywów ubezpiecze-

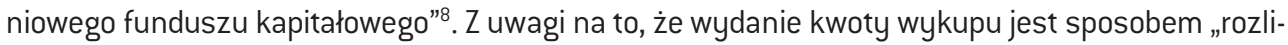
czenia" stron na skutek wypowiedzenia umowy przez ubezpieczającego, należyte wykonanie tego obowiązku należy uznać za wyznacznik należytego wykonania zobowiązania jako całego stosunku prawnego łączącego strony.

Istotne znaczenie ma fakt, że świadczenie wykupu w umowie ubezpieczenia z UFK nie zostało zdefiniowane w przepisach prawa, jest ono szczegółowo określane w umowie. Wprowadzenie do stosunku ubezpieczenia tego rodzaju świadczenia ma jednak podstawę prawną. W nowej ustawie o działalności ubezpieczeniowej i reasekuracyjnej (dalej: u.dz.u.r.) wart. 23 ust. 1 pkt 2 wskazano, że w umowie ubezpieczenia na życie, związanej z ubezpieczeniowym funduszem kapitałowym, o której mowa w dziale I w grupie 3 załącznika do ustawy, zakład ubezpieczeń określa: zasady ustalania wartości świadczeń z umowy ubezpieczenia z tytułu śmierci ubezpieczonego i dożycia ubezpieczonego do końca okresu ochrony ubezpieczeniowej, a także zasady ustalania wartości całkowitego i częściowego wykupu ubezpieczenia ${ }^{9}$. Magdalena Szczepańska twierdzi, że konstrukcja normy zawartej w art. 23 ust. 1 pkt 2 u.dz.u.r. jednoznacznie wskazuje, że wszystkie te świadczenia zostały potraktowane jako równorzędne. Jeżeli nie budzi wạtpliwości, że świadczenia z tytułu śmierci ubezpieczonego i dożycia ubezpieczonego do końca okresu ochrony ubezpieczeniowej są świadczeniami głównymi, to w konsekwencji - uwzględniając systematykę tego przepisu - należy uznać, że świadczenie wykupu również stanowi świadczenie

6. Ibidem, s. 5 ?

7. B. Kucharski, Świadczenie ubezpieczyciela w umowie ubezpieczenia mienia, Lex 2019.

8. W. Kamieński, op. cit., s. 56.

9. M. Szczepańska, Wypłata wartości wykupu w umowie ubezpieczenia na życie z ubezpieczeniowym funduszem kapitałowym - charakter prawny świadczenia, „Wiadomości Ubezpieczeniowe” 2015, nr 3, s. 101-102. 
główne ${ }^{10}$. Podobnie Michał Romanowski twierdzi, że gdyby uznać, że wartość wykupu nie jest świadczeniem głównym ubezpieczyciela, to konsekwentnie należałoby przyją́, że wypłata sumy ubezpieczenia z tytułu wystapienia zdarzenia ubezpieczeniowego (np. śmierć lub dożycie), finansowana ze składek wpłacanych przez ubezpieczających, również nie jest świadczeniem głównym ubezpieczyciela. Świadczenie wykupu, aby mogło być uznane za świadczenie uboczne, musiałoby być uznane za świadczenie pomocnicze, wspomagające realizację jakiegoś innego świadczenia głównego, ale trudno wskazać, jakie świadczenie ubezpieczyciela z umowy z UFK miałoby być „wspierane” przez świadczenie wykupu ${ }^{11}$. Argumentacja ta nie wydaje się przekonująca, dotyczy bowiem obowiązków ubezpieczyciela wynikających z umowy ubezpieczenia z UFK o charakterze ubezpieczeniowym, natomiast wydanie kwoty wykupu pozostaje w sferze obowiązków ubezpieczyciela z zakresu jego działalności inwestycyjnej.

W glosowanym orzeczeniu Sąd Najwyższy nie podzielił przedstawionych wyżej poglądów doktryny, trafnie wskazując, że ocena, iż mamy do czynienia z głównym świadczeniem stron przez pryzmat obligatoryjnych, wymienionych w ustawach warunków takiej umowy jest nietrafna. Nie można zgodzić się z stanowiskiem, że sam obowiązek uregulowania w treści czynności prawnej wartości wykupu powoduje, że staje się ona głównym świadczeniem stron. Ponadto Sąd Najwyższy wskazał, że ustawa o działalności ubezpieczeniowej i reasekuracyjnej dotyczy zagadnień o charakterze publicznoprawnym, a nie przesądza o kwalifikacji cywilnoprawnej takiej umowy. Argument ten nie wydaje się zasadny. Treść art. 23 ust. 1 pkt 2 u.dz.u.r. ma znaczenie zarówno dla wykładni cywilnoprawnej umowy ubezpieczenia, jak i dla OWU łączących strony. Przepis ten ustawodawca skierował do ubezpieczyciela, wskazując obligatoryjne elementy umowy ubezpieczenia z UFK, w tym określenie zasad ustalania wartości wykupu ubezpieczenia. Norma nie została jednak wyposażona w mechanizm sankcji. W celu ustalenia, czy wypłata kwoty wykupu ubezpieczenia stanowi główne świadczenie stron, należy dokonać wykładni OWU łączących strony, bowiem w ich treści znajduja się postanowienia dotyczące wydania i ustalenia wysokości kwoty wykupu. Wykładni wzorców powinno się dokonywać zgodnie z regułą ustanowioną w art. 65 §1 k.c. ${ }^{12}$, który stanowi że oświadczenie woli należy tłumaczyć tak, jak tego wymagaja - ze względu na okoliczności, w których zostało złożone - zasady współżycia społecznego oraz ustalone zwyczaje. Należy mieć również na uwadze to, że postanowienia OWU nie zostały objęte konsensusem, ale jednostronnie ukształtowane przez ubezpieczyciela. Umowa ubezpieczenia należy do umów szczególnego zaufania ${ }^{13}$, mających na celu zapewnienie ochrony osobie uprawnionej, zatem jej treść - jak również treść OWU - powinna być wykładana w taki sposób, aby tę ochronę zapewnić. Realizacja obowiązku wynikającego z art. 23 ust. 1 pkt 2 u.dz.u.r., to jest zapewnienie możliwości wykupu, nie może mieć zatem charakteru iluzorycznego, a ma takowy w sytuacji gdy większość środków pieniężnych zgromadzonych na koncie ubezpieczonego po realizacji wykupu „pozostaje w rękach ubezpieczyciela”. Ubezpieczający, zawierając umowę ubezpieczenia z UFK, działa w zaufaniu do ubezpieczyciela. Pozostaje w przekonaniu, że będzie uprawniony do wypowiedzenia umowy i gdy to się stanie, otrzyma sumę pieniężną odpowiadającą wartości jednostek uczestnictwa znajdujących się na jego indywidualnym

10. Ibidem, s. 102.

11. M. Romanowski, op. cit., s. 66.

12. M. Bednarek, [w] System prawa prywatnego. Prawo zobowiqzań - część ogólna. Tom V, [red.] E. Łętowska, Legalis 2020.

13. Wyrok Sądu Najwyższego z dnia 8 listopada 2018 r., sygn. II CSK 595/1?. 
rachunku. Ukształtowanie stosunku prawnego łączącego strony w ten sposób, że ubezpieczający nie ma możliwości wykupu bez znaczącej straty, jest sprzeczne z zasadami współżycia społecznego. Należy więc dokonać wykładni postanowień OWU określających zasady ustalania wysokości oraz wydania kwoty wykupu w sposób pozwalający ubezpieczającemu na zachowanie zgromadzonych na jego rachunku środków pieniężnych. Wydaje się zatem, że zakwalifikowanie wypłaty wykupu jako obowiązku niebędącego jednocześnie świadczeniem ubezpieczyciela, a jedynie czynnością o charakterze technicznym, tym samym niebędącá świadczeniem głównym stron, pozwala na zapewnienie ubezpieczonemu odpowiedniego poziomu ochrony prawnej.

Należy także zwrócić uwagę na wyrok Sądu Najwyższego z dnia 18 grudnia 2013 roku, w sprawie o sygn. I CSK 149/13, w którym sąd stwierdził, że klauzula zastrzegająca wygórowaną opłatę likwidacyjna jest niedozwolonym postanowieniem umownym, o którym mowa w art. $385^{1} \S 1$ zd. 1 k.c. W orzeczeniu tym wskazano, że przejęcie przez ubezpieczyciela całości lub znacznej części wartości jednostek uczestnictwa zgromadzonych na rachunku ubezpieczającego w oderwaniu od rozmiaru uiszczonych przez niego składek rażąco narusza interes konsumenta, a nadto jest wyrazem nierówności stron tego stosunku zobowiązaniowego, kształtuje bowiem prawa i obowiązki konsumenta w sposób sprzeczny z dobrymi obyczajami. Rozstrzygnięcie to koresponduje z linią orzeczniczą Sądu Ochrony Konkurencji i Konsumentów ${ }^{14}$. W wyroku z dnia 1 września 2011 roku w sprawie o sygn. XVII AmC 1941/11 Sąd Ochrony Konkurencji i Konsumentów wskazał, że opłata likwidacyjna stanowi świadczenie konsumenta, niebędące świadczeniem głównym, za bliżej nieokreślone czynności pozwanego. W ocenie Sądu postanowienie umowne przewidujace obowiązek spełnienia przez konsumenta na rzecz oferenta świadczenia, bez określenia jego charakteru lub ewentualnego świadczenia wzajemnego, jest sprzeczne z dobrymi obyczajami i rażąco narusza interes konsumentów. Natomiast w wyroku z dnia 4 czerwca 2012 roku w sprawie o sygn. XVII AmC 974/10 Sąd Ochrony Konkurencji i Konsumentów stwierdził, że ustawodawca nie określił, co należy rozumieć przez sformułowanie „główne świadczenia stron”, ale należałoby sądzić, że z reguły są to takie elementy konstrukcyjne umowy, bez których uzgodnienia nie doszłoby do jej zawarcia, czyli tzw. essentialia negotii. W niniejszym przypadku są to: ze strony pozwanej - świadczenie usług ubezpieczeniowych na rzecz konsumentów, ze strony zaś konsumenta - zapłata ceny za świadczone przez pozwanego usługi. W orzeczeniu tym Sąd nie uznał za świadczenie główne żadnego ze świadczeń o charakterze inwestycyjnym, wynikających z umowy ubezpieczenia z UFK. Na skutek tak ukształtowanego orzecznictwa w miejsce opłaty likwidacyjnej pojawiło się adekwatne umniejszanie kwoty wykupu. W pierwszych latach trwania ubezpieczenia wartość wykupu stanowić miała znikomy procent kwoty wykupu, tak aby w kolejnych latach zbliżać się do pełnej kwoty rezerwy techniczno-ubezpieczeniowej. Prowadzi to do efektu identycznego z pobraniem opłaty likwidacyjnej. W praktyce ubezpieczeniowej formalnie opłata likwidacyjna nie była pobierana (badź była pobierana zgodnie z orzecznictwem sądowym w wysokości odpowiadającej rzeczywistym kosztom rozwiązania umowy ubezpieczenia na życie z ubezpieczeniowym funduszem kapitałowym). Opłata likwidacyjna przyjęła postać opłaty ukrytej ${ }^{15}$. Zastrzeganie w umowach ubezpieczenia na życie z ubezpieczeniowym funduszem kapitałowym kwoty wykupu w takim kształcie,

14. Wyrok Sądu Ochrony Konkurencji i Konsumentów z dnia 1 września 2011 r. sygn. XVII AmC 1941/11; wyrok Sądu Ochrony Konkurencji i Konsumentów z dnia $?$ października 2011 r., sygn. XVII AmC 1704/09; wyrok Sądu Ochrony Konkurencji i Konsumentów z dnia 4 czerwca 2012 r., sygn. XVII AmC 974/10.

15. W. Kamieński, op. cit., s. 64. 
pozwala na przejęcie przez ubezpieczyciela całości lub znacznej części środków zgromadzonych na rachunku, stanowi więc ponowną próbę ukształtowania praw konsumenta w sposób sprzeczny z dobrymi obyczajami, rażąco naruszający jego interesy.

Podkreślenia wymaga, że wartość wykupu nie została w przedmiotowej sprawie uregulowana w umowie łączącej strony, a w OWU, które są pozaumownym źródłem praw i obowiązków stron. Spełnienie się ustawowych przesłanek związania adresata wzorca umowy jego treścią nie nadaje temu wzorcowi charakteru umowy, choć postanowienia wzorca wyznaczają - obok umowy będącej odrębną czynnością prawną - treść stosunku obligacyjnego ${ }^{16}$. Celem ogólnych warunków umów ubezpieczenia jest jedynie doprecyzowanie treści głównych świadczeń stron, a nie ich ukształtowanie. Za pomocą OWU ubezpieczyciel jednostronnie kształtuje treść świadczeń ubocznych oraz wykonuje obowiązi informacyjne. Dopuszczenie możliwości ukształtowania głównego świadczenia stron w treści wzorców umownych spowodowałoby akceptację nadużywania przez ubezpieczycieli silniejszej pozycji rynkowej. Technika zawierania umów z użyciem wzorca pozwala bowiem na łatwe jego wykorzystanie przez przedsiębiorców we własnym interesie i kosztem interesu klientów, umożliwiając narzucanie treści zawieranych umów ${ }^{17}$.

Ponadto wartość wykupu nie może zostać uznana za główne świadczenie stron umowy ubezpieczenia na życie z ubezpieczeniowym funduszem kapitałowym dlatego, że nie realizuje jej podstawowego długoterminowego celu. Roszczenie powstaje tylko w wypadku chęci przedterminowego zakończenia stosunku prawnego łączącego ubezpieczyciela z ubezpieczającym. Nie w każdym stosunku prawnym konieczność takiej wypłaty zaistnieje. Ubezpieczający bowiem w momencie zawierania umowy z ubezpieczeniowym funduszem kapitałowym nie ma zamiaru rozwiązania jej przed terminem. Taki zamiar pojawia się dopiero na etapie wykonywania umowy. Przedterminowe zakończenie wykonywania umowy stanowi sytuację wyjątkową, a postanowienia dotyczące niestandardowych, wyjątkowych sposobów zakończenia stosunku prawnego nie moga zostać uznane za główne świadczenia stron. Istotny wydaje się również brak świadczenia wzajemnego po stronie ubezpieczyciela. Stosunek prawny powstały między ubezpieczycielem a ubezpieczającym powinien charakteryzować się ekwiwalentnością. W przypadku kwoty wykupu świadczenie ubezpieczyciela nie tyle nawet nie odpowiada swoją wartością świadczeniu ubezpieczającego, ile - nie istnieje. Niedopuszczalne prawnie jest zastrzeżenie opłaty za dokonanie czynności, która nie ma charakteru dostatecznie wyodrębnionego prawnie świadczenia; w kategoriach cywilistycznych "opłata” powinna być traktowana jako wynagrodzenie za spełnienie świadczenia. Tak jak wypłata środków z rachunku bankowego, tak i wypłata wartości wykupu ma charakter czynności technicznej. Sam fakt generowania kosztów przez dokonanie czynności technicznej nie uzasadnia jeszcze pobrania z tego tytułu opłaty jako ekwiwalentu ich poniesienia ${ }^{18}$. Co więcej, ubezpieczajacy płaci ubezpieczycielowi za skorzystanie z uprawnienia przyznanego mu przez ustawodawcę w art. 23 ust. 1 pkt. 2 u.dz.u.r., jak również w art. 830 k.c. ${ }^{19}$ Niedozwolone są postanowienia umowne

16. R. Trzaskowski, Kodeks cywilny. Komentarz. Tom III. Zobowiqzania. Część ogólna, [red.] J. Gudowski, Lex 2017.

17. M. Bednarek, [w] System prawa prywatnego. Prawo zobowiqzań - część ogólna. Tom V, [red.] E. Łętowska, Legalis 2020.

18. W. Kamieński, Glosa do wyroku Sqdu Apelacyjnego w Warszawie z dnia 14 maja 2010 r., „Rozprawy Ubezpieczeniowe" 2012, nr 2(13), s. 182.

19. Uprawnienie prawnokształtujące ubezpieczającego do wypowiedzenia umowy ubezpieczenia w każdym czasie. 
uszczuplające ustawowe uprawnienia konsumenta. Nałożenie we wzorcu umowy na konsumenta obowiązku zapłaty kwoty pieniężnej, i to w znacznej wysokości, w razie skorzystania przez niego z prawa przyznanego mu w ustawie jest sprzeczne zarówno z ustawą, jak i dobrymi obyczajami, gdyż zmierza do ograniczenia ustawowego prawa konsumenta, czyniąc ekonomicznie nieopłacalnym korzystanie z tego prawa ${ }^{20}$.

Sąd Najwyższy w glosowanym orzeczeniu trafnie stwierdził, że przepis art. $385^{1} \S 1$ zdanie 2 k.c. powinien być wykładany wąsko. Taki sposób interpretacji jest spójny z wcześniej prezentowanymi poglądami zarówno przedstawicieli doktryny ${ }^{21}$, jak i judykatury. Między innymi w wyroku z dnia z dnia 8 czerwca 2004 roku w sprawie o sygn. I CK 635/03 Sad Najwyższy wskazał, że „pojęcie głównych świadczeń stron należy bowiem [...] - interpretować raczej wąsko, w nawiązaniu do elementów przedmiotowo istotnych umowy. Przemawia za tym treść przepisu: ustawodawca posłużył się terminem »postanowienia określające główne świadczenia stron«, a nie zwrotem »dotyczące« takiego świadczenia, który ma szerszy zakres".

Sąd Najwyższy w glosowanym orzeczeniu dokonał zatem prawidłowej kwalifikacji świadczenia wykupu, wskazując, że świadczeniami podstawowymi ubezpieczenia na życie z ubezpieczeniowym funduszem kapitałowym są: obowiązek zapłaty składek przez ubezpieczającego oraz obowiązek zarządzania wniesionymi w ten sposób środkami przez ubezpieczyciela i dokonania wypłat w razie zaistnienia jednego ze zdarzeń objętych ubezpieczeniem (śmierci lub dożycia do określonego dnia). Podzielił tym samym stanowisko wcześniej prezentowane w doktrynie, zgodnie z którym w umowie ubezpieczenia na życie z ubezpieczeniowym funduszem kapitałowym zobowiązanie ubezpieczyciela obejmuje dwa świadczenia główne: wypłatę sumy ubezpieczenia na wypadek śmierci osoby ubezpieczonej oraz zarządzanie na zlecenie ubezpieczającego, lecz nie na jego rachunek, aktywami ubezpieczeniowego funduszu kapitałowego. Świadczeniom tym odpowiadaja dwa główne świadczenia ubezpieczającego: zapłata składki oraz zapłata opłaty za zarządzanie 22 . Glosowana uchwała zasługuje na pełną aprobatę także dlatego, że Sąd Najwyższy, wydając ją, nie poprzestał na ustawodawstwie krajowym. Analizie poddano zarówno normy prawa unijnego, jak również orzecznictwo Trybunału Sprawiedliwości Unii Europejskiej. Uchwała ta jest zatem w pełni zgodna i z normami, i z orzecznictwem na szczeblu unijnym ${ }^{23}$. Jest to istotne, gdyż dokonanie wy-

20. Ibidem, s. 183

21. A. Rzetecka-Gil, Kodeks cywilny. Komentarz. Zobowiqzania. Część ogólna, Lex 2011: „Wskazuje się, że określenie główne świadczenia stron należy interpretować raczej wąsko, w nawiązaniu do pojęcia elementów umowy przedmiotowo istotnych (essentialia negotii)." K. Skubisz-Kępka, Kodeks cywilny. Komentarz. Tom III. Zobowiqzania. Część ogólna (art. 353-534), [red.] M. Fras, M. Habdas, Lex 2018: „Zdaniem SN pojęcie głównych świadczeń stron należy interpretować raczej wąsko, w nawiązaniu do elementów przedmiotowo istotnych umowy. Przemawia za tym treść przepisu: ustawodawca posłużył się terminem postanowienia określajqce główne świadczenia stron, a nie [...] dotyczqce takiego świadczenia, który ma szerszy zakres”. „Głównymi świadczeniami stron sa, choć nie tylko, elementy przedmiotowo istotne (essentialia negotii) umowy jako czynności prawnej (np. cena, świadczenie wzajemne) w odróżnieniu od ubocznych, takich jak wysokość odsetek za zwłokę w zapłacie ceny albo klauzula waloryzacyjna".

22. W. Kamieński, Główne..., s. 56.

23. Orzeczenia Trybunału Sprawiedliwości Unii Europejskiej: z dnia 10 września 2014 r. w sprawie C-34/13, Monika Kušionová przeciwko SMART Capital a.s., EU:C:2014:2189; z dnia 3 czerwca 2010 r. w sprawie C-484/08, Caja de Ahorros y Monte de Piedad de Madrid przeciwko Asociación de Usuarios de Servicios Bancarios (Ausbanc), EU:C:2010:309; z dnia 7 grudnia 2006 r. w sprawie C-13/06, Komisja Wspólnot Europejskich przeciwko Republice Greckiej, EU:C:2006:765. 
kładni polskiej ustawy transponującej dyrektywę w sposób niezgodny z treścią dyrektywy zinterpretowanej przez Trybunał Sprawiedliwości stanowiłoby naruszenie prawa Unii Europejskiej i rodziłoby odpowiedzialność państwa przed Trybunałem, jak również odpowiedzialność odszkodowawczą skarbu państwa wobec podmiotów prywatnych ${ }^{24}$. W uzasadnieniu orzeczenia Sąd Najwyższy słusznie wskazał, że do rozstrzygnięcia zagadnienia prawnego w pierwszej kolejności należy dokonać wykładni art. 4 ust. 2 dyrektywy Rady 93/13/EWG z dnia 5 kwietnia 1993 roku w sprawie nieuczciwych warunków w umowach konsumenckich, gdyż art. 3851 § 1 zd. 2 k.c. stanowi jego implementację $e^{25}$. Norma ta była wielokrotnie przedmiotem rozważań Trybunału Sprawiedliwości Unii Europejskiej. Trybunał wskazał ogólny kierunek interpretacji przepisów wiążący sądy krajowe. Należy zatem stwierdzić, że Sąd Najwyższy słusznie powołuje się na orzecznictwo Trybunału Sprawiedliwości, w którym stwierdzono, że wyjątek zawarty w art. 4 ust. 2 dyrektywy 93/13 odnosi się do klauzul określających „podstawowe świadczenia w ramach danej umowy i które z tego względu charakteryzują tę umowę [...]. Natomiast warunki, które wskazują charakter posiłkowy względem warunków definiujących samą istotę stosunku umownego, nie mogą być objęte pojęciem głównego przedmiotu umowy w rozumieniu tego przepisu"26. We wskazanych przez Sąd Najwyższy orzeczeniach Trybunał stwierdza również, że art. 4 ust. 2 dyrektywy podlega wykładni zawężającej $^{27}$, a wszystkie wạtpliwości powinny być interpretowane na korzyść konsumenta ${ }^{28}$. Analizując zatem charakter prawny świadczenia wykupu, trzeba mieć na względzie zasady wskazane przez Trybunał. To zaś uniemożliwia uznanie kwoty wykupu za świadczenie główne.

Podsumowujac, należy stwierdzić, że glosowana uchwała stanowi kolejny krok Sądu Najwyższego poczyniony w celu ułatwienia ubezpieczonym klientom dochodzenia swoich roszczeń z tytułu umów ubezpieczenia z ubezpieczeniowym funduszem kapitałowym. Powoduje ona konieczność badania przez sądy postanowień dotyczących wartości wykupu pod kątem ich abuzywności. Orzeczenie to skutkować będzie ujednoliceniem orzecznictwa sądów powszechnych, a w konsekwencji zmniejszeniem niepewności klientów, których interesy zostały naruszone na skutek postanowień umownych sprzecznych z prawem oraz dobrymi obyczajami.

\section{Wykaz źródeł}

Bednarek M., [w] System prawa prywatnego. Prawo zobowiqzań - część ogólna. Tom V, Łętowska E. [red.], Legalis 2020 .

24. P. Machnikowski, Zagadnienia prawne i ekonomiczne dotyczqce umów ubezpieczeń na życie, [red.] M. Szczepańska, Lex 2017.

25. Dyrektywa Rady 93/13/EWG w art. 4 ust. 2 wskazuje, że ocena nieuczciwego charakteru warunków nie dotyczy ani określenia głównego przedmiotu umowy, ani relacji ceny i wynagrodzenia do dostarczonych w zamian towarów lub usług, o ile warunki te zostały wyrażone prostym i zrozumiałym językiem.

26. Wyrok Trybunału Sprawiedliwości Unii Europejskiej z dnia 30 kwietnia 2014 r. w sprawie C-26/13 Árpád Kásler, Hajnalka Káslerné Rábai przeciwko OTP Jelzálogbank Zrt.

27. Wyrok Trybunału Sprawiedliwości Unii Europejskiej z dnia 26 lutego 2015 r. w sprawie C-143/13 Bogdan Matei i loana Ofelia Matei przeciwko SC Volksbank România SA.

28. Wyrok Trybunału Sprawiedliwości Unii Europejskiej z dnia 23 kwietnia 2015 r. w sprawie C-96/14 Jean-Claude Van Hove przeciwko CNP Assurances SA. 
Kamieński W., Glosa do wyroku Sqdu Apelacyjnego w Warszawie z dnia 14 maja 2010 r., „Rozprawy Ubezpieczeniowe" 2012, nr 2(13).

Kamieński W., Główne świadczenia stron umowy ubezpieczenia na życie z ubezpieczeniowym funduszem kapitałowym, „Rozprawy Ubezpieczeniowe” 2014, nr 1 ?.

Kucharski B., Świadczenie ubezpieczyciela w umowie ubezpieczenia mienia, Lex 2019.

Machnikowski P., Zagadnienia prawne i ekonomiczne dotyczq̨ce umów ubezpieczeń na życie, Szczepańska M. [red.], Lex 2017.

Raport Rzecznika Finansowego, Ubezpieczenia na życie z ubezpieczeniowym funduszem kapitałowym, Warszawa 2012.

Raport Rzecznika Finansowego, Ubezpieczenia na życie z ubezpieczeniowym funduszem kapitałowym. Część II, Warszawa 2016.

Romanowski M., Czy świadczenie wykupu w umowach z UFK jest świadczeniem głównym?,

„Wiadomości Ubezpieczeniowe” 2016, nr 2.

Rzetecka-Gil A., Kodeks cywilny. Komentarz. Zobowiqzania - część ogólna, Lex 2011.

Skubisz-Kępka K., Kodeks cywilny. Komentarz. Tom III. Zobowiqzania. Część ogólna (art. 353-534), Fras M., Habdas M. [red.], Lex 2018.

Szczepańska M., Wypłata wartości wykupu w umowie ubezpieczenia na życie z ubezpieczeniowym funduszem kapitałowym - charakter prawny świadczenia, „Wiadomości Ubezpieczeniowe” $2015, \mathrm{nr} 3$.

Trzaskowski R., Kodeks cywilny. Komentarz. Tom III. Zobowiqzania. Część ogólna, Gudowski J. [red.], Lex 2017.

\section{Gloss to resolution of the supreme Court of 24 January 2020, court file no. III CZP 51/19}

The purpose of this gloss is to discuss the resolution of the Supreme Court dated 24 January 2020 issued in the case no. III CZP 51/19. The resolution was issued in response to a legal question referred by the District Court in Szczecin in connection with discrepancies in case law. The discussed resolution concerns the legal nature of the redemption amount paid by the insurer in the event of early termination of a life insurance contract with an insurance capital fund. In the opinion of the author, the Supreme Court correctly indicated that the redemption amount paid by the insurer in the event of early termination of the life insurance contract with an insurance capital fund is not the main provision, nor is it a provision within the meaning of art. 353 of the Civil Code The provisions of the contract specifying the "redemption provision, redemption value, redemption amount" are therefore subject to control from the point of view of their abusiveness.

Key words: insurance capital fund, redemption provision, redemption value, insurance contract, contract termination.

KATARZYNA WAŁDOCH - Katedra Prawa Cywilnego Wydziału Prawa i Administracji Uniwersytetu Gdańskiego.

e-mail: katarzyna.waldoch@ug.edu.pl

ORCID:0000-0003-2594-1408 